\title{
PARD3 Gene
}

National Cancer Institute

\section{Source}

National Cancer Institute. PARD3 Gene. NCI Thesaurus. Code C125526.

This gene is involved in asymmetric cell division, signal transduction, and tig ht junction formation. 